\title{
Do meta-emotion strategies and their effects vary in students between their family home and their university home?
}

\author{
Warren Mansell ${ }^{1}$ (D) $\cdot$ Annabelle Barnes ${ }^{1} \cdot$ Laura Grant $^{1} \cdot$ Lauren Maria De Sousa $^{1}$
}

Published online: 15 August 2020

(C) The Author(s) 2020

\begin{abstract}
Different meta-emotion strategies are often categorised as either adaptive (e.g. compassionate care) or maladaptive (e.g. suppression). Yet some evidence indicates that the same strategy can be adaptive in one culture and maladaptive in another. We aimed to test whether meta-emotion strategies and their effects can in fact vary across different social contexts within the same individuals. A total of 140 students completed measures of meta-emotion strategies, satisfaction with life scale, and anxiety. Each scale was adapted for both the family home and the university home context. On average, the students had a lower level of interest in their emotions and adopted a tough control to a lesser extent when in the family home, compared to the university home context. At the individual level, some students used suppression more in the family home than the university home, whereas for others the effect was reversed. A series of multiple regressions showed the context specificity of meta-emotion strategies. Students who reported greater suppression of their emotions were more anxious, but only within the home context that these had both been measured. Yet, the relationship with life satisfaction was transferred across contexts; suppression in the family home (but not suppression at university) predicted less satisfaction with life at university. For other strategies (tough control, anger and compassionate care), their relationship with satisfaction with life at university was only predicted by the extent to which the participants reported using these strategies at university, and not in relation to their use in the family home.
\end{abstract}

Keywords Emotional regulation $\cdot$ Psychological functioning $\cdot$ Context $\cdot$ Perceptual control theory $\cdot$ Meta-emotion $\cdot$ Social role

Meta-emotions may be defined as the emotional response towards our emotional states (Norman and Furnes 2014). Whilst meta-emotion is viewed as a separate construct to emotion itself, it is closely intertwined with emotional regulation, the process by which we monitor, evaluate and deal with emotions in order to accomplish personal goals (Berking and Wupperman 2012; Koole 2009). Within the psychological literature, meta-emotion may be viewed as the driving force for emotion regulation as a desire to alter the intensity, duration or experience of emotions is guided by the way we feel about them (Berking and Wupperman 2012). The kinds of strategies that can be recognised as meta-emotions include

Warren Mansell

warren.mansell@manchester.ac.uk

1 Division of Psychology and Mental Health, School of Health Sciences, Faculty of Biology, Medicine and Health, CeNTrUM Centre for New Treatments and Understanding in Mental Health, University of Manchester, Manchester Academic Health Science Centre, 2nd Floor Zochonis Building, Brunswick Street, Manchester M13 9PL, UK treating their emotions with anger, compassionate care, interest, contempt/shame, tough control (e.g. being stern with oneself), and suppression (e.g. fighting against one's emotions) (Mitmansgruber et al. 2008). It is recognised that metaemotions are closely related to the clinical field of emotional schemas and meta-cognitive theory, and yet the fields have largely developed independently from one another (Edwards and Wupperman 2019). There is also a potential overlap with transactional theories that focus on explaining the developmental origins of excessive emotional reactivity (Linehan 1987). For example, certain vulnerable individuals may be biologically predisposed to greater emotional reactivity, whilst additionally growing up in a family in which certain emotions are regarded as shameful or unacceptable.

A key question is whether meta-emotional strategies are of benefit (helpful or adaptive) to people or whether they make their difficulties worse (unhelpful or maladaptive). It is of course hard to operationalise this dichotomy - but in the absence of a definition, studies have typically considered the maladaptive strategies as ones used more by people with psychiatric disorders and assessed whether using them is associated with worsening of symptoms. Conversely, strategies used 
more frequently by people who report low levels of mental health problems, and that predict improvements in well-being - such as satisfaction with life measures - are considered to be adaptive.

One overview of this question was provided by a metaanalysis of 70 studies which found that negative attitudes towards emotion are associated with symptoms of depression, and this equated to a medium-to-large effect size (Yoon et al. 2018). Suppression is one example of a meta-emotion strategy that has been widely researched and has been found to be elevated in a range of mental health disorders (for reviews, see Aldao et al. 2010; Berking and Wupperman 2012; Chawla and Ostafin 2007; Gross and John 2003; Hayes et al. 1996; Purdon 1999). In comparison to those who accept their emotions, persistent use of suppressive or avoidant regulation styles is related to lower life satisfaction (Gross and John 2003; Haga et al. 2007) and increased anxiety related symptoms (CampellSillis et al. 2006; Hofmann et al. 2009). However, this simple view of suppression as maladaptive is not supported by crosscultural studies (for a review, see Edwards and Wupperman 2019). For example, in Asian participants, the use of suppression allowed better psychological adjustment to chronic disease (De Ridder et al. 2008). Similarly, compared to European controls, students from Hong Kong did not experience poorer psychological functioning in terms of life satisfaction as a result of using suppression (Soto et al. 2011).

Thus, strategies adopted may fluctuate on a situational basis (Bonanno and Burton 2013). For example, a surgeon faced with an emergency situation, may require suppression to complete their role. Mitmansgruber et al. (2009) provided evidence for this notion with the discovery that in a sample of paramedics, tough control and experiential avoidance were viewed as helpful for wellbeing when engaging with a patient. Furthermore, in a review of the transdiagnostic processes underlying psychopathology, Morris and Mansell (2018) discovered that it may not be psychological processes themselves which determine distress, but the breadth with which they are adopted. For example, whilst suppression is not problematic in all cases, it may become so when used persistently. Whilst many individuals use suppression to some extent, those who adopt it flexibly on the basis of contextual demands may not experience reduced wellbeing (Morris and Mansell 2018).

The theoretical framework of perceptual control theory (PCT; Powers 1973) may be applied to provide an explanation for the contextual basis of meta-emotion strategies. PCT is a theory centred around the concept of control and the idea that as humans, we seek to gain control over perceived aspects of our environment; this is the nature of a goal (Powers 1973). PCT states that goals are organised in a hierarchical fashion with higher level goals that relate broadly to the sense of self and lower level goals that become increasingly concrete (Alsawy et al. 2014; Powers 1973). Higher level goals such as the desire to avoid rejection feed into lower level goals such as the desire to conceal specific signs of anxiety (Alsawy et al. 2014).
Most importantly, PCT states that a loss of control in relation to one's higher level goals is implicated in psychological distress (Alsawy et al. 2014; Powers 1973). For example, in the case of social anxiety, distress may be experienced as a result of conflict between the higher level goals of both avoiding rejection and engaging in fulfilling social interaction (Alsawy et al. 2014). Various studies (largely in student samples) have shown support for this finding that goal conflict is associated with reduced life satisfaction and increased symptoms of anxiety (Kelly et al. 2015).

PCT may be viewed as particularly relevant for metaemotion research as by definition, we utilise meta-emotion strategies to accomplish our goals (Berking and Wupperman 2012; Koole 2009). Moreover, its focus on the role of goal conflict for psychological distress may shed light on why certain strategies may only become problematic when in conflict with important goals (Alsawy et al. 2014). For example, suppression may not be problematic when in line with university home goals such as completing an assignment, but may become so when opposing a family home goal of receiving emotional support.

This research aimed to consider the meta-emotion strategies adopted by first year university students and whether they differed contextually between the family and university home. Not only this, but it looked to consider the relationship of these strategies to life satisfaction and anxiety for each home context, two concepts that have been closely related to adaptive or maladaptive meta-emotion strategies in previous literature. First year university students may be viewed as a compelling population as leaving the family home is often a period of social, financial and psychological change (Friedlander et al. 2007).

Whilst previous research has acknowledged that seemingly maladaptive strategies may be flexible (Bonanno and Burton 2013; Morris and Mansell 2018) or useful in a certain context (Mitmansgruber et al. 2009), this research sought to provide a clear extension via the comparison of two contexts. It has not yet been demonstrated that context may be crucial not only for the adoption of different strategies in the same individual, but for the relationship of these strategies to psychological functioning. Despite being largely exploratory, it is hoped that if contextual findings are exemplified in university students, this may provide novel research for the role of context in ER, as well as act as a pilot for future research regarding the metaemotion strategies adopted between work and home for individuals who work in potentially stressful environments.

Our first hypothesis was that there would be a significant difference in the meta-emotion strategies of students between the family home and university home contexts. Our second hypothesis was that the relationship found between strategies and life satisfaction and anxiety would be specific to the home context in which they are measured. 


\section{Method}

\section{Design}

A within-participant's research design was adopted with the independent variable of home context in which meta-emotion was considered. This had two levels - family home and university home. The dependent variable for the first hypothesis was the score on the meta-emotion scale (MES; Mitmansgruber et al. 2009) for each meta-emotion subscale. The dependent variables for the second hypothesis were scores on the satisfaction with life scale (SWLS; Diener et al. 1985) and the generalised anxiety disorder scale (GAD-7; Spitzer et al. 2006). The order in which participants completed each set of questionnaires was counterbalanced.

All participants accessed questionnaires online via a student research participation scheme, and upon doing so, received credits towards a first year module. Each questionnaire set was clearly labelled for the family or university home context. Both sets of each scale stated that participants bear the specific context in mind (each item also specified the context) and were asked to answer questions 'in terms of your actual experiences, not how you think you should react'. This research was Ethics Division approved [2017-2660-3964] 04/10/17.

\section{Participants}

Participants were 140 first year Psychology students. The recruitment advert stated that participants must be in their first year of university and must be living away from the family home; they should also have visited their family home some time during term or term time break. Nonetheless, a total of 13 participants were removed from the original sample: two who stated they did not live away from home, eleven who were in their second year and one who did not state their year of study. There were exclusion criteria relating to mental health symptoms, treatment, or past trauma in order to be as inclusive as possible; to address any possible distress, contact details for the university counselling service and the Samaritans were provided. Based on demographic data for first year psychology undergraduates, participants were aged between 17 and 49 years, $\mathrm{M}=$ 18.74, $\mathrm{SD}=2.32$. The gender breakdown was $80.1 \%$ female and $19.9 \%$ male. Participants visited their family home at varying time points with 50 returning once a month, 62 once a term and 13 outside of University term time. The ethnicity of our sample was White British $(n=91)$, White other $(n=17)$, Pakistani $(n=5)$, Chinese $(n=4)$, Indian $(n=4)$, other Chinese mix $(n=$ $3)$, other Asian $(n=1)$, African $(n=1)$, other mixed $(n=$ $1)$ and prefer not to say $(n=1)$.

\section{Measures}

Materials consisted of the MES (Mitmansgruber et al. 2009), the SWLS (Diener et al. 1985), the GAD-7 (Spitzer et al. 2006) and the received support scale (RSS; Krause and Markides 1990). The RSS (Krause and Markides 1990) was not used for final analyses but included for future research purposes.

There were two copies of the MES (Mitmansgruber et al. 2009), one per context. Each included 28 questions in relation to six meta-emotion subscales; four depicted negative metaemotions (anger, contempt/shame, tough control, suppression) and two positive meta-emotions (compassionate care and interest). All questions were adapted for specificity regarding either the family or university home context; 'when in the family/university home, I often think my emotional reaction is wrong' (anger), 'when I feel burdened by my emotions in the family/university home, I am kind to myself' (compassionate care), 'I learn through my feelings when in the family/university home' (interest), 'at the family/ university home, repeatedly, there are situations when I excoriate myself'(contempt/shame), 'when I am sad or anxious in the family/university home, I become very demanding of myself' (tough control), and 'I fight strongly against my emotions in the family/university home' (suppression). The final item in the contempt/shame subscale was inversely coded; 'when I cannot live up to my own expectations in the family/ university home, I do not put myself down'. A higher score on the MES (5; completely true for me) indicated greater use of the meta-emotion whilst a lower score (1; untrue for me) indicated lower use. Although not widely used to date, the measure was developed through interviews with both patients and clinical psychologists specifically for research regarding meta-emotion experiences in terms of both individuals' knowledge and reactions towards emotional states (Mitmansgruber et al. 2009), making it highly suitable for the current research.

There were two copies of the SWLS (Diener et al. 1985), one per context. The SWLS consisted of five items measuring 'global cognitive judgements' of life satisfaction which were adapted for context such as; 'the conditions of my family/ university home are excellent'. A third original version of the SWLS was not used in analyses but included for future research. A high score (6; strongly agree) indicated high life satisfaction and a low score (1; strongly disagree) dissatisfaction with life. The SWLS has been demonstrated to assess wellbeing in terms of life satisfaction both cross culturally and across varying ages, backgrounds and levels of psychological wellbeing (Pavot and Diener 1993). Furthermore, it has been shown to have strong internal reliability, to be relatively consistent for measuring life satisfaction over time and to hold strong negative correlations with clinical measures such as the Beck depression inventory (Beck 1961; Pavot and Diener 1993). 
There were two copies of the GAD-7 (Spitzer et al. 2006), one per context which remained unchanged from the original with the exception of the title made context specific; 'over the last two weeks, how often have you been bothered by any of the following problems in the family/university home'. The GAD-7 consisted of 7 items related to DSM criteria for generalised anxiety disorder such as 'not being able to stop or control worrying.' High scores (4; nearly every day) demonstrated more persistent and disabling symptoms of anxiety and low scores $(1 ;$ not at all) related to low levels of anxiety. The GAD-7 has been demonstrated to generalise to primary care, clinical samples and the general population across age and gender (Kroenke et al. 2010; Löwe et al. 2008). Moreover, it has been shown to measure generalised anxiety disorder in terms of prevalence, specificity and disability as well as other anxiety disorders such as social anxiety and panic disorder (Ruiz et al. 2011). It scores from 0 to 21, with a threshold of 8 indicating the need for a clinical intervention. The measure has good internal consistency, Cronbach's alpha $=0.92$ (Kroenke et al. 2010).

For researcher interpretation, at the end of each scale an optional text box was included for comments regarding important aspects of meta-emotion, life satisfaction or anxiety in either home context. These were included for future research but not included in analyses.

\section{Statistical Analyses}

To investigate the first hypothesis, a paired t-test assessed whether there was a group difference in the meta-emotion strategies of students between home contexts for each of the MES subscales. Secondly, a one-sample t-test tested for intraindividual differences in the meta-emotion strategies of students between family and university home contexts. To avoid a difference on the basis of chance alone, the one-sample t-test was carried out at test the sample for only MES subscales with an absolute difference greater than 1. A Bonferroni correction was not applied to avoid the concealment of potentially meaningful results.

For the second hypothesis, regression analyses were carried out across both home contexts for each dependent variable, making for four separate hierarchical stepwise regressions. We chose to use multiple regressions, entering all of the MES subscales together, because we regarded it as essential to identify the independent contribution of each subscale to outcomes when controlling for the contribution of the others. These regressions considered SWLS (family home), GAD-7 (family home), SWLS (university home) and GAD-7 (university home). For each regression, predictor variables (each MES subscale) in step 1 included the opposite context to the outcome being considered in order to assess the general effects of meta-emotion strategies independent of their situation-specific effects. In step 2, both the opposite and identical context were entered together to assess the additional variance accounted for by matching the context of the strategy with the context of the outcome measure. This method of analysis allowed us to specify which subscale, in which home context, was independently associated with the outcome variable, when accounting for all other other subscales in both contexts.

\section{Results}

The normality of data was determined via visual checks of histograms and tests of skewness and kurtosis. All values lay within the 'acceptable' range of -2 and +2 , and all but one variable were in the range of -1 to +1 .

\section{Differences in the Use of Different Meta-Emotion Strategies across Contexts}

A paired sample t-test showed a significant group difference for interest $t(139)=3.32, p<.001, d=0.28$ and tough control $t(139)=2.25, p<.05, d=0.19$, between the two home contexts; students generally had a lower score of interest in their emotions and lower use of tough control in the family home compared to the university home. The one sample t-test on the absolute differences in meta-emotion strategies showed a significant difference for suppression only, $t(139)=2.59$, $p<.05, d=0.22$. This effect emerged for suppression in the absence of a group effect, indicating that individual students reported engaging in suppression to different degrees in the family home compared to the university home, but not in a consistent direction across the sample.

\section{Correlations}

Table 1 displays the zero-order correlations between the each of the six strategies within family and within university, and each of the two dependent variables of satisfaction with life and anxiety, within family and university. Most correlations were statistically significant and in the expected direction, with the exception of the strategy of interest in emotions which did not correlate with life satisfaction or anxiety. The correlations tended to be higher where the social context was matched between the strategy and the outcome, with maximums of over $r=0.5$.

\section{Predictions of Satisfaction with Life and Anxiety at the Family Home}

The first hierarchical stepwise regression assessed the role of home context in the relationship between meta-emotion strategies and satisfaction with life at the family home (See Table 2). The first step tested how well satisfaction with life 
Table 1 Zero-Order Correlations between Meta-emotion Strategies, and Anxiety and Satisfaction with Life, across Family and University Contexts

\begin{tabular}{|c|c|c|c|c|c|}
\hline \multirow{2}{*}{\multicolumn{2}{|c|}{ Predictor Variable in Each Context }} & \multicolumn{4}{|c|}{ Dependent Variable in Each Context } \\
\hline & & \multicolumn{2}{|l|}{ Family } & \multicolumn{2}{|l|}{ University } \\
\hline & & Satisfaction with Life & Anxiety & Satisfaction with Life & Anxiety \\
\hline \multirow[t]{6}{*}{ Family } & Anger & $-.38 * * *$ & $.37 * * *$ & -.15 & $.27 * * *$ \\
\hline & Compassionate & $.20 *$ & -.12 & $.25 * *$ & -.15 \\
\hline & Interest & -.01 & .02 & .10 & .10 \\
\hline & Contempt & $-.36 * * *$ & $.39 * * *$ & $-.35 * * *$ & $.45^{* * *}$ \\
\hline & Tough Control & $-.40 * * *$ & $.27 * * *$ & $-.22 * *$ & $.27 * * *$ \\
\hline & Suppression & $-.48 * * *$ & $.45 * * *$ & $-.31 * * *$ & $.32 * * *$ \\
\hline \multirow[t]{6}{*}{ University } & Anger & $-.22 * *$ & $.20 *$ & $-.43 * * *$ & $.47 * * *$ \\
\hline & Compassionate & $.21 *$ & -.12 & $.38 * * *$ & -.16 \\
\hline & Interest & .09 & .02 & $.20 *$ & .03 \\
\hline & Contempt & $-.20^{*}$ & $.31 * * *$ & $-.37 * * *$ & $.48^{* * * *}$ \\
\hline & Tough Control & $-.22 *$ & $.19^{*}$ & $-.35 * * *$ & $.52 * * *$ \\
\hline & Suppression & -.14 & $.27 * * *$ & $-.31 * * *$ & $.52 * * *$ \\
\hline
\end{tabular}

Bold denotes matching contexts for the predictor and outcome variable. $* \mathrm{p}<.05 * * \mathrm{p}<.01 * * * \mathrm{p}<.001$ in the family home could be predicted by meta-emotion strategies that were not from the same home context. It revealed a significant effect of meta-emotion strategies carried out at the university home on the measures of satisfaction with life reported at the family home in step $1, R^{2}=.11, R^{2}$ change $=.11$, $F(6,133)=2.79, p=0.01$, accounting for $11 \%$ of the total variance. When the strategies carried out in the family home were added in step 2, a total of $34 \%$ of variance was now explained, $R^{2}=.34, R^{2}$ change $=.23, F(12,127)=5.55$, $p<.001$. Specifically, showing interest in emotions at university related to greater satisfaction with life in the other home context - with the family.

The second stepwise regression assessed the role of home context on anxiety at the family home (See Table 3 ). The first step tested how well anxiety in the family home could be predicted by meta-emotion strategies that were not from the same home context. It revealed that meta-emotion strategies carried out at the university home accounted for $12 \%$ of the variance in anxiety at the family home in step $1, R^{2}=.12, R^{2}$ change $=.12, F(6,133)=3.13, p=.007$. When the strategies carried out in the family home were added in step 2, a total of $28 \%$ of variance was now explained, $R^{2}=.28, R^{2}$ change = $.16, F(12,127)=4.19, p<.001$. Specifically, suppressing emotions in the family home (but not the university home) predicted anxiety in the family home.

\section{Predictions of Satisfaction with Life and Anxiety at the University Home}

The third stepwise regression assessed the role of home context on satisfaction with life at the university home (See Table 4). The first step tested how well satisfaction with life in the university home could be predicted by meta-emotion strategies that were not from the same home context. When only the strategies used in the family home were entered in step 1,20\% of the variance was explained, $R^{2}=.20, R^{2}$ change $=.20, F(6,133)=5.49$, $p<.001$. This increased to $41 \%$ when strategies from the university home were added in step $2, R^{2}=.41, R^{2}$ change $=.21, F$ $(12,127)=7.44, p<.001$. The effects were distributed quite widely across a number of strategies. Most of these were specific to the university home: tough control and anger at university (but not in the family home) were related to lower satisfaction with life at university, and compassionate care and interest at university (but not in the family home) were related to higher satisfaction with life at university. In addition, suppressing emotions in the family home predicted less satisfaction with life at university (Table 4).

The final hierarchical stepwise regression assessed the role of home context on the relationship between meta-emotion strategies and anxiety at university (Table 5). The first step tested how well anxiety in the university home could be predicted by meta-emotion strategies that were not from the same home context. It revealed that meta-emotion strategies carried out at the family home accounted for $23 \%$ of the variance in anxiety at the family home in step $1, R^{2}=.23, R^{2}$ change $=.23$, $F(6,133)=6.65, p<.001$. This was $43 \%$ when strategies from the university home were added in step $2, R^{2}=.38, R^{2}$ change $=.20, F(12,127)=8.10, p<.001$. Specifically, tough control and suppression at the university home (but not in the family home) predicted anxiety at university.

\section{Discussion}

Students were found to adopt different meta-emotion strategies between family home and university home contexts, 
Table 2 Regression Analysis for Satisfaction with Life in the Family home

\begin{tabular}{|c|c|c|c|c|c|}
\hline Model/outcome variable & Step & Predictor & B (std.error) & $\beta$ & $95 \% \mathrm{CI}$ \\
\hline Life satisfaction & 1 & Anger & $-0.77(0.10)$ & -.09 & {$[-0.27,0.12]$} \\
\hline (Family home) & & (University home) & & & \\
\hline Life satisfaction & 1 & Compassionate care & $0.17(0.09)$ & .17 & {$[-0.01,0.35]$} \\
\hline (Family home) & & (University home) & & & \\
\hline Life satisfaction & 1 & Interest & $0.90(0.90)$ & $.10 * *$ & {$[-0.09,0.27]$} \\
\hline (Family home) & & (University home) & & & \\
\hline Life satisfaction & 1 & Contempt/shame & $-0.05(0.11)$ & -.05 & {$[-0.27,0.17]$} \\
\hline (Family home) & & (University home) & & & \\
\hline Life satisfaction & 1 & Tough control & $-0.22(0.12)$ & -.23 & {$[-0.46,9.17]$} \\
\hline (Family home) & & (University home) & & & \\
\hline Life satisfaction & 1 & Suppression & $0.06(0.10)$ & .07 & {$[-0.14,0.26]$} \\
\hline (Family home) & & (University home) & & & \\
\hline Life satisfaction & 2 & Anger & -0.06 & -.06 & {$[-0.24,0.12]$} \\
\hline (Family home) & & (University home) & $(0.09)$ & & \\
\hline Life satisfaction & 2 & Compassionate care & $0.15(0.10)$ & .25 & {$[-0.05,0.34]$} \\
\hline (Family home) & & (University home) & & & \\
\hline Life satisfaction & 2 & Interest & 0.20 & $.21 *$ & {$[0.02,0.38]$} \\
\hline (Family home) & & (University home) & $(0.09)$ & & \\
\hline Life satisfaction & 2 & Contempt/shame & $0.04(0.11)$ & .04 & {$[-0.18,0.26]$} \\
\hline (Family home) & & (University home) & & & \\
\hline Life satisfaction & 2 & Tough control & -0.10 & -.12 & {$[-0.33,0.13]$} \\
\hline (Family home) & & University home) & $(0.12)$ & & \\
\hline Life satisfaction & 2 & Suppression & 0.10 & .12 & {$[-0.09,0.28]$} \\
\hline (Family home) & & (University home) & $(0.09)$ & & \\
\hline Life satisfaction & 2 & Anger & $-0.12(0.86)$ & -.14 & {$[-0.29,0.05]$} \\
\hline (Family home) & & (Family home) & & & \\
\hline Life satisfaction & 2 & Compassionate care & $0.03(0.11)$ & .03 & {$[-0.19,0.26]$} \\
\hline (Family home) & & (Family home) & & & \\
\hline Life satisfaction & 2 & Interest & $-0.09(0.10)$ & -.09 & {$[-0.28,0.12]$} \\
\hline (Family home) & & (Family home) & & & \\
\hline Life satisfaction & 2 & Contempt/shame & $-0.01(0.12)$ & -.02 & {$[-0.25,0.21]$} \\
\hline (Family home) & & (Family home) & & & \\
\hline Life satisfaction & 2 & Tough control & $-0.15(0.11)$ & -.16 & {$[-0.36,0.06]$} \\
\hline (Family home) & & (Family home) & & & \\
\hline
\end{tabular}

$\mathrm{df}=139, \mathrm{p}<.05^{*}, \mathrm{p}<.01 * *$. providing partial support of our first hypothesis. As a group, students appeared to have a lower level of interest in their emotions and adopt tough control to a lesser extent when in the family home compared to the university home context. The difference in level of interest in emotions was a strong effect that would be a statistically significant finding $(p<.001)$ when accounting for multiple comparisons; the difference in tough control was weaker and would not remain statistically significant $(p<.05)$ when accounting for multiple comparisons. To date it appears that no other distinct difference in meta-emotion regulation strategies between social contexts has been demonstrated outside of distinctly different cultures.

There was also an indication that students suppressed their emotions in one context more readily than another, but that this varied between students. It is possible that some first year students found suppression more useful in the university home in order to be in line with the goals of this context such as to complete work, but less useful in the family home where they feel more at ease expressing their feelings. However, this could be the opposite for those students who instead find suppression useful in a family home in which emotional expression is less acceptable, but less so at university where their goal is to express themselves. It is important to note that the statistical test used to reveal these within-individual differences used an arbitrary difference in score of over 1, which could be challenged.

We also found that the addition of context changed the profile of the relationship between meta-emotion strategies and both life satisfaction and anxiety, across both the home and university contexts. Some of these effects were strong $(p<.01)$, and would have been statistically significant when 
Table 3 Regression Analysis for Anxiety in the Family home

\begin{tabular}{|c|c|c|c|c|c|}
\hline Model/outcome variable & Step & Predictor & $\begin{array}{l}\text { B } \\
\text { (std.error) }\end{array}$ & $\beta$ & $95 \% \mathrm{CI}$ \\
\hline $\begin{array}{l}\text { Anxiety } \\
\text { (Family home) }\end{array}$ & 1 & $\begin{array}{l}\text { Anger } \\
\text { (University home) }\end{array}$ & $\begin{array}{l}-0.02 \\
(0.07)\end{array}$ & -.04 & {$[-0.15,0.12]$} \\
\hline $\begin{array}{l}\text { Anxiety } \\
\text { (Family home) }\end{array}$ & 1 & $\begin{array}{l}\text { Compassionate care } \\
\text { (University home) }\end{array}$ & $\begin{array}{l}-0.08 \\
(0.06)\end{array}$ & -.12 & {$[-0.20,0.05]$} \\
\hline $\begin{array}{l}\text { Anxiety } \\
\text { (Family home) }\end{array}$ & 1 & $\begin{array}{l}\text { Interest } \\
\text { (University home) }\end{array}$ & $\begin{array}{l}0.02 \\
(0.06)\end{array}$ & .002 & {$[-0.12,0.14]$} \\
\hline $\begin{array}{l}\text { Anxiety } \\
\text { (Family home) }\end{array}$ & 1 & Contempt/shame (University home) & $\begin{array}{l}0.18 \\
(0.08)\end{array}$ & $.25^{*}$ & {$[0.03,0.33]$} \\
\hline $\begin{array}{l}\text { Anxiety } \\
\text { (Family home) }\end{array}$ & 1 & $\begin{array}{l}\text { Tough control } \\
\text { (University home) }\end{array}$ & $\begin{array}{l}-0.05 \\
(0.08)\end{array}$ & -.07 & {$[-0.21,0.12]$} \\
\hline $\begin{array}{l}\text { Anxiety } \\
\text { (Family home) }\end{array}$ & 1 & $\begin{array}{l}\text { Suppression } \\
\text { (University home) }\end{array}$ & $\begin{array}{l}0.12 \\
(0.07)\end{array}$ & .20 & {$[0.02,0.25]$} \\
\hline $\begin{array}{l}\text { Anxiety } \\
\text { (Family home) }\end{array}$ & 2 & $\begin{array}{l}\text { Anger } \\
\text { (University home) }\end{array}$ & $\begin{array}{l}-0.04 \\
(0.06)\end{array}$ & -.06 & {$[-0.16,0.09]$} \\
\hline $\begin{array}{l}\text { Anxiety } \\
\text { (Family home) }\end{array}$ & 2 & Compassionate care (University home) & $\begin{array}{l}-0.06 \\
(0.07)\end{array}$ & -.09 & {$[-0.16,0.10]$} \\
\hline $\begin{array}{l}\text { Anxiety } \\
\text { (Family home) }\end{array}$ & 2 & $\begin{array}{l}\text { Interest } \\
\text { (University home) }\end{array}$ & $\begin{array}{l}-0.03 \\
(0.06)\end{array}$ & -.05 & {$[-0.16,0.10]$} \\
\hline $\begin{array}{l}\text { Anxiety } \\
\text { (Family home) }\end{array}$ & 2 & Contempt/shame (University home) & $\begin{array}{l}0.10 \\
(0.08)\end{array}$ & .14 & {$[-0.06,0.25]$} \\
\hline $\begin{array}{l}\text { Anxiety } \\
\text { (Family home) }\end{array}$ & 2 & $\begin{array}{l}\text { Tough control } \\
\text { (University home) }\end{array}$ & $\begin{array}{l}0.06 \\
(0.08)\end{array}$ & -.10 & {$[-0.23,0.10]$} \\
\hline $\begin{array}{l}\text { Anxiety } \\
\text { (Family home) }\end{array}$ & 2 & $\begin{array}{l}\text { Suppression } \\
\text { (University home) }\end{array}$ & $\begin{array}{l}0.08 \\
(0.06)\end{array}$ & .15 & {$[-0.04,0.21]$} \\
\hline $\begin{array}{l}\text { Anxiety } \\
\text { (Family home) }\end{array}$ & 2 & $\begin{array}{l}\text { Anger } \\
\text { (Family home) }\end{array}$ & $\begin{array}{l}0.10 \\
(0.06)\end{array}$ & .17 & {$[-0.02,0.22]$} \\
\hline $\begin{array}{l}\text { Anxiety } \\
\text { (Family home) }\end{array}$ & 2 & Compassionate care (Family home) & $\begin{array}{l}-0.00 \\
(0.08)\end{array}$ & .00 & {$[-0.16,0.16]$} \\
\hline $\begin{array}{l}\text { Anxiety } \\
\text { (Family home) }\end{array}$ & 2 & $\begin{array}{l}\text { Interest } \\
\text { (Family home) }\end{array}$ & $\begin{array}{l}0.02 \\
(0.07)\end{array}$ & .03 & {$[-0.12,0.15]$} \\
\hline $\begin{array}{l}\text { Anxiety } \\
\text { (Family home) }\end{array}$ & 2 & $\begin{array}{l}\text { Contempt/shame } \\
\text { (Family home) }\end{array}$ & $\begin{array}{l}0.09 \\
(0.08)\end{array}$ & .12 & {$[-0.08,0.25]$} \\
\hline $\begin{array}{l}\text { Anxiety } \\
\text { (Family home) }\end{array}$ & 2 & $\begin{array}{l}\text { Tough control } \\
\text { (Family home) }\end{array}$ & $\begin{array}{l}-0.06 \\
(0.08)\end{array}$ & -.09 & {$[-0.21,0.09]$} \\
\hline $\begin{array}{l}\text { Anxiety } \\
\text { (Family home) }\end{array}$ & 2 & $\begin{array}{l}\text { Suppression } \\
\text { (Family home) }\end{array}$ & $\begin{array}{l}0.17 \\
(0.06)\end{array}$ & $.31 * *$ & {$[0.05,0.29]$} \\
\hline
\end{tabular}

$\mathrm{df}=139, \mathrm{p}<.05^{*}, \mathrm{p}<.01 * *$.

accounting for the (four) multiple comparisons. However, other effects were modest $(p<.05)$ and would not have been statistically significant when accounting for multiple comparisions.

There were a variety of findings that related to different types of meta-emotion strategy. Emotion suppression is typically found to be maladaptive when measured broadly with no specific reference to context (Aldao et al. 2010; Berking and Wupperman 2012). Yet, our study found that suppression only predicted anxiety when it was measured in the same home context; suppression in the family home did not predict anxiety at university and suppression at university did not predict anxiety in the family home. For the strategies of tough control, anger and compassionate care, their relationship with satisfaction with life at university was only predicted by the extent to which the participants reported using these strategies at university, and not in relation to their use in the family home.
The above findings challenge the idea that suppression can be thought of as a trait-like strategy as currently assumed within existing self-report questionnaires - which do not ask about different contexts. However, we did not find evidence, as in cross-cultural studies (e.g. Wei et al. 2013), that a maladaptive strategy can switch to being adaptive in a different context. Such evidence would provide stronger support for the view, presented by our PCT model (Morris and Mansell 2018), that it is the nature of the current goal within the current context that determines whether any psychological process is adaptive or maladaptive, rather than the process itself. The family-versus-university context contrast of the current study may not be stark enough to bring out this difference; whereas studying the use of suppression in challenging work contexts (e.g. emergency personnel) in future studies may bring out this difference. Earlier research has found adaptive relationships that contrast with the wider literature when measured purely 
Table 4 Regression Analysis for Satisfaction with Life in the University home

\begin{tabular}{|c|c|c|c|c|c|}
\hline Model/outcome variable & Step & Predictor & $\begin{array}{l}\text { B } \\
\text { (std. error) }\end{array}$ & $\beta$ & $95 \% \mathrm{CI}$ \\
\hline Life satisfaction (University home) & 1 & $\begin{array}{l}\text { Anger } \\
\text { (Family home) }\end{array}$ & $0.11(0.09)$ & .14 & {$[-0.05,0.28]$} \\
\hline Life satisfaction (University home) & 1 & $\begin{array}{l}\text { Compassionate care } \\
\text { (Family home) }\end{array}$ & $0.18(0.09)$ & .19 & {$[-0.01,0.36]$} \\
\hline Life satisfaction (University home) & 1 & $\begin{array}{l}\text { Interest } \\
\text { (Family home) }\end{array}$ & $0.05(0.09)$ & .05 & {$[-0.13,0.22]$} \\
\hline Life satisfaction (University home) & 1 & Contempt/shame (Family home) & $-0.25(0.10)$ & $-.25 *$ & {$[-0.45,-0.05]$} \\
\hline Life satisfaction (University home) & 1 & Tough control (Family home) & $0.01(0.10)$ & .01 & {$[-0.19,0.21]$} \\
\hline $\begin{array}{l}\text { Life satisfaction } \\
\text { (University home) }\end{array}$ & 1 & $\begin{array}{l}\text { Suppression } \\
\text { (Family home) }\end{array}$ & $-0.21(0.09)$ & $-.26^{*}$ & {$[-0.38,-0.04]$} \\
\hline $\begin{array}{l}\text { Life satisfaction } \\
\text { (University home) }\end{array}$ & 2 & $\begin{array}{l}\text { Anger } \\
\text { (Family home) }\end{array}$ & $\begin{array}{r}0.08 \\
(0.08)\end{array}$ & .09 & {$[-0.08,0.24]$} \\
\hline $\begin{array}{l}\text { Life satisfaction } \\
\text { (University home) }\end{array}$ & 2 & $\begin{array}{l}\text { Compassionate care } \\
\text { (Family home) }\end{array}$ & $\begin{array}{l}-0.07 \\
(0.10)\end{array}$ & -.07 & {$[-0.27,0.14]$} \\
\hline $\begin{array}{l}\text { Life satisfaction } \\
\text { (University home) }\end{array}$ & 2 & $\begin{array}{l}\text { Interest } \\
\text { (Family home) }\end{array}$ & $\begin{array}{r}0.01 \\
(0.09)\end{array}$ & .01 & {$[-0.17,0.19]$} \\
\hline $\begin{array}{l}\text { Life satisfaction } \\
\text { (University home) }\end{array}$ & 2 & $\begin{array}{l}\text { Contempt/shame } \\
\text { (Family home) }\end{array}$ & $\begin{array}{l}-0.10 \\
(0.11)\end{array}$ & -.10 & {$[-0.30,0.11]$} \\
\hline $\begin{array}{l}\text { Life satisfaction } \\
\text { (University home) }\end{array}$ & 2 & $\begin{array}{l}\text { Tough control } \\
\text { (Family home) }\end{array}$ & $\begin{array}{r}0.05 \\
(0.10)\end{array}$ & .05 & {$[-0.14,0.24]$} \\
\hline $\begin{array}{l}\text { Life satisfaction } \\
\text { (University home) }\end{array}$ & 2 & $\begin{array}{l}\text { Suppression } \\
\text { (Family home) }\end{array}$ & $\begin{array}{l}-0.21 \\
(0.08)\end{array}$ & $-.26 * *$ & {$[-0.37,-0.05]$} \\
\hline $\begin{array}{l}\text { Life satisfaction } \\
\text { (University home) }\end{array}$ & 2 & $\begin{array}{l}\text { Anger } \\
\text { (University home) }\end{array}$ & $\begin{array}{l}-0.21 \\
(0.08)\end{array}$ & $-.24 *$ & {$[-0.37,-0.05]$} \\
\hline $\begin{array}{l}\text { Life satisfaction } \\
\text { (University home) }\end{array}$ & 2 & $\begin{array}{l}\text { Compassionate care } \\
\text { (University home) }\end{array}$ & $0.26(0.09)$ & $.28 * *$ & {$[0.09,0.33]$} \\
\hline $\begin{array}{l}\text { Life satisfaction } \\
\text { (University home) }\end{array}$ & 2 & $\begin{array}{l}\text { Interest } \\
\text { (University home) }\end{array}$ & $0.21(0.08)$ & $.23^{*}$ & {$[0.04,0.37]$} \\
\hline $\begin{array}{l}\text { Life satisfaction } \\
\text { (University home) }\end{array}$ & 2 & Contempt/shame (University home) & $-0.00(0.10)$ & -.00 & {$[-0.20,0.20]$} \\
\hline $\begin{array}{l}\text { Life satisfaction } \\
\text { (University home) }\end{array}$ & 2 & Tough control (University home) & $-0.25(0.11)$ & $-.27 *$ & {$[-0.46,-0.04]$} \\
\hline $\begin{array}{l}\text { Life satisfaction } \\
\text { (University home) }\end{array}$ & 2 & Suppression (University home) & $0.02(0.08)$ & .03 & {$[-0.14,0.18]$} \\
\hline
\end{tabular}

$\mathrm{df}=139, \mathrm{p}<.05^{*}, \mathrm{p}<.01^{* *}$.

within the work context (e.g. Mitmansgruber et al. 2009), but they have not studied these differences within individuals by comparing home versus work contexts.

With regard to measures of satisfaction with life, suppression in the family home (but not suppression at university) predicted less satisfaction with life at university. This transfer of effects across contexts was also found for interest in emotions, which was higher at university for students who reported greater satisfaction with their life at their family home. These findings show that by assessing the social context of meta-emotion strategies, their more complex effects may be identified. It is hard to speculate on the meaning of these specific findings, but one might speculate that going to university from a family environment of suppression might be problematic because of the 'open and expressive' nature of life at university. One might also speculate that a background of a satisfying family life might allow students to take a stronger interest in their emotions as they face the challenges of university life.
Generally, our findings are consistent with studies investigating cross-cultural differences, in that a strategy can be associated with poorer functioning in one context and not in another. Specifically, there is evidence that specific strategies that are typically thought of as 'dysfunctional', are not found to be associated with poorer psychological functioning in nonWestern cultures, such as Hong Kong Chinese (Soto et al. 2011), American Chinese (Wei et al. 2013), and Korean cultures (Kwon et al. 2013). Yet, our study extends this cross-context difference to a within-individual difference in social context.

Limitations of this study centre around the potential bias of the student sample. Based on demographic data, the majority of participants were likely to be female which may have skewed results as research suggests women tend to adopt a wider range of both adaptive and maladaptive emotion regulation strategies (NolenHoeksema and Aldao 2011; Tamres et al. 2002). Generally, younger age groups are also thought use emotion regulation to a greater extent, although this is not the case for suppression, which is 
Table 5 Regression Analysis for Anxiety in the University home

\begin{tabular}{|c|c|c|c|c|c|}
\hline Model/outcome variable & Step & Predictor & $\begin{array}{l}\text { B } \\
\text { (std. error) }\end{array}$ & $\beta$ & $95 \% \mathrm{CI}$ \\
\hline $\begin{array}{l}\text { Anxiety } \\
\text { (University home) }\end{array}$ & 1 & $\begin{array}{l}\text { Anger } \\
\text { (Family home) }\end{array}$ & $0.02(0.06)$ & .03 & {$[-0.10,0.14]$} \\
\hline $\begin{array}{l}\text { Anxiety } \\
\text { (University home) }\end{array}$ & 1 & $\begin{array}{l}\text { Compassionate care } \\
\text { (Family home) }\end{array}$ & $-0.09(0.07)$ & -.13 & {$[-0.22,0.04]$} \\
\hline $\begin{array}{l}\text { Anxiety } \\
\text { (University home) }\end{array}$ & 1 & $\begin{array}{l}\text { Interest } \\
\text { (Family home) }\end{array}$ & $0.08(0.06)$ & -.12 & {$[-0.04,0.20]$} \\
\hline $\begin{array}{l}\text { Anxiety } \\
\text { (University home) }\end{array}$ & 1 & $\begin{array}{l}\text { Contempt/shame } \\
\text { (Family home) }\end{array}$ & $0.27(0.07)$ & $.37 * * *$ & {$[0.12,0.41]$} \\
\hline $\begin{array}{l}\text { Anxiety } \\
\text { (University home) }\end{array}$ & 1 & $\begin{array}{l}\text { Tough control } \\
\text { (Family home) }\end{array}$ & $-0.05(0.07)$ & -.07 & {$[-0.19,0.09]$} \\
\hline $\begin{array}{l}\text { Anxiety } \\
\text { (University home) }\end{array}$ & 1 & $\begin{array}{l}\text { Suppression } \\
\text { (Family home) }\end{array}$ & $0.07(0.06)$ & .12 & {$[-0.05,0.19]$} \\
\hline $\begin{array}{l}\text { Anxiety } \\
\text { (University home) }\end{array}$ & 2 & $\begin{array}{l}\text { Anger } \\
\text { (Family home) }\end{array}$ & $\begin{array}{r}0.00 \\
(0.06)\end{array}$ & .00 & {$[-0.11,0.11]$} \\
\hline $\begin{array}{l}\text { Anxiety } \\
\text { (University home) }\end{array}$ & 2 & $\begin{array}{l}\text { Compassionate care } \\
\text { (Family home) }\end{array}$ & $\begin{array}{l}-0.03 \\
(0.08)\end{array}$ & -.05 & {$[-0.18,0.11]$} \\
\hline $\begin{array}{l}\text { Anxiety } \\
\text { (University home) }\end{array}$ & 2 & $\begin{array}{l}\text { Interest } \\
\text { (Family home) }\end{array}$ & $\begin{array}{r}0.08 \\
(0.06)\end{array}$ & .11 & {$[-0.05,0.20]$} \\
\hline $\begin{array}{l}\text { Anxiety } \\
\text { (University home) }\end{array}$ & 2 & $\begin{array}{l}\text { Contempt/shame } \\
\text { (Family home) }\end{array}$ & $\begin{array}{r}0.13 \\
(0.08)\end{array}$ & .17 & {$[-0.02,0.27]$} \\
\hline $\begin{array}{l}\text { Anxiety } \\
\text { (University home) }\end{array}$ & 2 & $\begin{array}{l}\text { Tough control } \\
\text { (Family home) }\end{array}$ & $\begin{array}{l}-0.11 \\
(0.07)\end{array}$ & -.17 & {$[-0.25,0.02]$} \\
\hline $\begin{array}{l}\text { Anxiety } \\
\text { (University home) }\end{array}$ & 2 & $\begin{array}{l}\text { Suppression } \\
\text { (Family home) }\end{array}$ & $\begin{array}{c}0.08 \\
(0.06)\end{array}$ & .14 & {$[-0.03,0.19]$} \\
\hline $\begin{array}{l}\text { Anxiety } \\
\text { (University home) }\end{array}$ & 2 & $\begin{array}{l}\text { Anger } \\
\text { (University home) }\end{array}$ & $\begin{array}{r}0.07 \\
(0.06)\end{array}$ & .11 & {$[-0.05,0.19]$} \\
\hline $\begin{array}{l}\text { Anxiety } \\
\text { (University home) }\end{array}$ & 2 & $\begin{array}{l}\text { Compassionate care } \\
\text { (University home) }\end{array}$ & $\begin{array}{l}-0.07 \\
(0.07)\end{array}$ & -.10 & {$[-1.20,0.06]$} \\
\hline $\begin{array}{l}\text { Anxiety } \\
\text { (University home) }\end{array}$ & 2 & $\begin{array}{l}\text { Interest } \\
\text { (University home) }\end{array}$ & $\begin{array}{l}-0.05 \\
(0.06)\end{array}$ & -.08 & {$[-0.17,0.07]$} \\
\hline $\begin{array}{l}\text { Anxiety } \\
\text { (University home) }\end{array}$ & 2 & Contempt/shame (University home) & $\begin{array}{r}0.05 \\
(0.07)\end{array}$ & .08 & {$[-0.09,0.20]$} \\
\hline $\begin{array}{l}\text { Anxiety } \\
\text { (University home) }\end{array}$ & 2 & $\begin{array}{l}\text { Tough control } \\
\text { (University home) }\end{array}$ & $\begin{array}{r}0.17 \\
(0.08)\end{array}$ & $.25^{*}$ & {$[0.02,0.32]$} \\
\hline $\begin{array}{l}\text { Anxiety } \\
\text { (University home) }\end{array}$ & 2 & $\begin{array}{l}\text { Suppression } \\
\text { (University home) }\end{array}$ & $\begin{array}{c}0.12 \\
(0.06)\end{array}$ & $.20 *$ & {$[0.01,0.24]$} \\
\hline
\end{tabular}

$\mathrm{df}=139, \mathrm{p}<.05^{*}, \mathrm{p}<.01^{* *}$.

greater, on average, in older populations (Tamres et al. 2002). Additionally, the collection of data via self-report may be questioned as participants may have inaccurately self-reported on their own emotion regulation, or responses may have been biased by negative mood or demand characteristics particularly if they feel they regulate in a maladaptive way (Aldao et al. 2010).

To strengthen findings, future studies may wish to implement the completion of scales in the specified context. This was done by Mitmansgruber et al. (2009), but was not possible in the current research due to time restrictions of family home visits. In relation to PCT (Powers 1973), research may wish to incorporate the measurement of participants' goals in order to better understand why differences in meta-emotion regulation strategies and their relationship to psychological functioning occur in relation to goals in each context. An ideal way to study this would be to use a case-series modelling approach in which the goals and strategies of each individual are assessed within each of their social contexts. This would permit the inference of the facilitating and interfering effects of each strategy for each of that individual's goals, which then would be tested prospectively through participant diary records. For example, the strategy of suppression might meet the goal of keeping harmony in the family home and yet make it hard to meet the goal of building meaningful relationships at university. The PCT approach would be supported if the individual models showed a better fit to prospectively collected data than models constructed from theories that do not conceptualise the adaptive/maladaptive nature of meta-emotion strategies at this individualised goal level (see Mansell and Huddy 2018).

Finally, a practical implication of our findings is that clinicians working in university counseling centers may need consider the potential differences between how students relate to their feelings at home versus at university, and the impact of this on their wellbeing. At a wider level, our results indicate that it may be fruitful 
for therapists to remain curious and open-minded as to whether any meta-emotion strategy they report is problematic or beneficial to the individual within their current situation. This is encapsulated by the approach guided by PCT, known as Method of Levels (Carey 2006). Rather than working on training in any specific meta-emotion strategy, it is designed to help clients to identify and explore where their own goals (and strategies) may be in conflict, and to begin to resolve them for themselves.

In conclusion, this research has demonstrated that context is key to meta-emotion regulation both in terms of fluctuating strategies on a group and intra-individual level, and the shifting relationship between emotion regulation and life satisfaction and anxiety on the basis of context. It is particularly important for future research to focus on populations who experience diverse social roles (e.g. emergency personnel, military) in which the use and impact of strategies is likely to vary much more widely than the student population, and therefore be more critical to understand and help address.

Authors' Contributions W. Mansell conceived of the study and codesigned it A. Barnes, L. Grant and L. De Sousa. Data was collected by A.Barnes, L. Grant and L. De Sousa. With the support and editing of W. Mansell, A Barnes, L. Grant and L. De Sousa analysed and wrote up the study. The results of this study have not been presented elsewhere. This research received no specific grant from any funding agency, commercial or not-for-profit sectors.

\section{Compliance with Ethical Standards}

Conflict of Interest There are no conflicts of interest with respect to this manuscript.

Ethical Approval This research was approved at the Division level of the University Research Ethics Committee [2017-2660-3964] 04/10/17.

Informed Consent Informed consent was obtained from all participants. The authors have abided by the Ethical Principles of Psychologists and Code of Conduct as set out by the APA. The University Division subcommittee approved of the study [2017-2660-3964] 04/10/17.

Open Access This article is licensed under a Creative Commons Attribution 4.0 International License, which permits use, sharing, adaptation, distribution and reproduction in any medium or format, as long as you give appropriate credit to the original author(s) and the source, provide a link to the Creative Commons licence, and indicate if changes were made. The images or other third party material in this article are included in the article's Creative Commons licence, unless indicated otherwise in a credit line to the material. If material is not included in the article's Creative Commons licence and your intended use is not permitted by statutory regulation or exceeds the permitted use, you will need to obtain permission directly from the copyright holder. To view a copy of this licence, visit http://creativecommons.org/licenses/by/4.0/.

\section{References}

Aldao, A., Nolen-Hoeksema, S., \& Schweizer, S. (2010). Emotionregulation strategies across psychopathology: A meta-analytic review. Clinical Psychology Review, 30(2), 217-237. https://doi. org/10.1016/j.cpr.2009.11.004.

Alsawy, S., Mansell, W., Carey, T. A., McEvoy, P., \& Tai, S. J. (2014). Science and practice of transdiagnostic CBT: A perceptual control theory (PCT) approach. International Journal of Cognitive Therapy, 7(4), 334-359. https://doi.org/10.1521/ijct.2014.7.4.334.

Beck, A. (1961). An inventory for measuring depression. Archives of General Psychiatry, 4(6), 561. https://doi.org/10.1001/archpsyc. 1961.01710120031004.

Berking, M., \& Wupperman, P. (2012). Emotion regulation and mental health. Current Opinion in Psychiatry, 25(2), 128-134. https://doi. org/10.1097/YCO.0b013e3283503669.

Bonanno, G., \& Burton, C. (2013). Regulatory flexibility: An individual differences perspective on coping and emotion regulation. Perspectives on Psychological Science, 8(6), 591-612. https://doi. org/10.1177/1745691613504116.

Campell-Sillis, L., Barlow, D. H., Brown, T. A., \& Hofmann, S. G. (2006). Effects of suppression and acceptance on emotional responses of individuals with anxiety and mood disorders. Behaviour Research and Therapy, 44(9), 1251-1263.

Carey, T. A. (2006). The method of levels: How to do psychotherapy without getting in the way. Living Control Systems Publishing.

Chawla, N., \& Ostafin, B. (2007). Experiential avoidance as a functional dimensional approach to psychopathology: An empirical review. Journal of Clinical Psychology, 63(9), 871-890. https://doi.org/10. 1002/jclp.20400.

De Ridder, D., Geenen, R., Kuijer, R., \& van Middendorp, H. (2008). Psychological adjustment to chronic disease. The Lancet, 372(9634), 246-255.

Diener, E., Emmons, R. A., Larsen, R. J., \& Griffin, S. (1985). The satisfaction with life scale. Journal of Personality Assessment, 49(1), 71-75.

Edwards, E. R., \& Wupperman, P. (2019). Research on emotional schemas: A review of findings and challenges. Clinical Psychologist, 23(1), 3-14.

Friedlander, L., Reid, G., Shupak, N., \& Cribbie, R. (2007). Social support, self-esteem, and stress as predictors of adjustment to university among first-year undergraduates. Journal of College Student Development, 48(3), 259-274.

Gross, J., \& John, O. (2003). Individual differences in two emotion regulation processes: Implications for affect, relationships, and wellbeing. Journal of Personality and Social Psychology, 85(2), 348362. https://doi.org/10.1037/0022-3514.85.2.348.

Haga, S., Kraft, P., \& Corby, E. (2007). Emotion regulation: Antecedents and well-being outcomes of cognitive reappraisal and expressive suppression in cross-cultural samples. Journal of Happiness Studies, 10(3), 271-291. https://doi.org/10.1007/s10902-007-90803.

Hayes, S., Wilson, K., Gifford, E., \& Follette, V. (1996). Experiential avoidance and behavioral disorders: A functional dimensional approach to diagnosis and treatment. Journal of Consulting and Clinical Psychology, 64(6), 1152-1168. https://doi.org/10.1037/ 0022-006X.64.6.1152.

Hofmann, S. G., Heering, S., Sawyer, A. T., \& Asnaani, A. (2009). How to handle anxiety: The effects of reappraisal, acceptance, and suppression strategies on anxious arousal. Behaviour Research and Therapy, 47(5), 389-394. https://doi.org/10.1016/j.brat.2009.02. 010.

Kelly, R., Mansell, W., \& Wood, A. (2015). Goal conflict and well-being: A review and hierarchical model of goal conflict, ambivalence, selfdiscrepancy and self- concordance. Personality and Individual Differences, 85, 212-229. https://doi.org/10.1016/j.paid.2015.05. 011.

Koole, S. (2009). The psychology of emotion regulation: An integrative review. Cognition \& Emotion, 23(1), 4-41. https://doi.org/10.1080/ 02699930802619031. 
Krause, N., \& Markides, K. (1990). Measuring social support among older adults. The International Journal of Aging and Human Development, 30(1), 37-53. https://doi.org/10.2190/CY26XCKW-WY1V-VGK3.

Kroenke, K., Spitzer, R., Williams, J., \& Löwe, B. (2010). The patient health questionnaire somatic, anxiety, and depressive symptom scales: A systematic review. General Hospital Psychiatry, 32(4), 345-359.

Kwon, H., Yoon, K. L., Joormann, J., \& Kwon, J. H. (2013). Cultural and gender differences in emotion regulation: Relation to depression. Cognition \& Emotion, 27(5), 769-782.

Linehan, M. M. (1987). Dialectical behavior therapy for borderline personality disorder: Theory and method. Bulletin of the Menninger Clinic, 51(3), 261-276.

Löwe, B., Decker, O., Müller, S., Brähler, E., Schellberg, D., Herzog, W., \& Herzberg, P. (2008). Validation and standardization of the generalized anxiety disorder screener (GAD-7) in the general population. Medical Care, 46(3), 266-274. https://doi.org/10.1097/mlr. 0b013e318160d093.

Mansell, W., \& Huddy, V. (2018). The assessment and modeling of perceptual control: A transformation in research methodology to address the replication crisis. Review of General Psychology, 22(3), 305-320.

Mitmansgruber, H., Beck, T., \& Schüßler, G. (2008). "Mindful helpers": Experiential avoidance, meta-emotions, and emotion regulation in paramedics. Journal of Research in Personality, 42(5), 1358-1363. https://doi.org/10.1016/j.jrp.2008.03.012.

Mitmansgruber, H., Beck, T., Höfer, S., \& Schüßler, G. (2009). When you don't like what you feel: Experiential avoidance, mindfulness and meta-emotion in emotion regulation. Personality and Individual Differences, 46(4), 448-453.

Morris, L., \& Mansell, W. (2018). A systematic review of the relationship between rigidity/flexibility and transdiagnostic cognitive and behavioral processes that maintain psychopathology. Journal of Experimental Psychopathology, 9(3), 2043808718779431.

Norman, E., \& Furnes, B. (2014). The concept of "meta emotion": What is there to learn from research on metacognition? Emotion Review, 8(2), 187-193.

Nolen-Hoeksema, S., \& Aldao, A. (2011). Gender and age differences in emotion regulation strategies and their relationship to depressive symptoms. Personality and Individual Differences, 51(6), 704708. https://doi.org/10.1016/j.paid.2011.06.012.

Pavot, W., \& Diener, E. (1993). Review of the satisfaction with life scale. Psychological Assessment, 5(2), 164-172. https://doi.org/10.1037// 1040-3590.5.2.164.

Powers, W. T. (1973). Behaviour: The control of perception. Chicago: Aldine.

Purdon, C. (1999). Thought suppression and psychopathology. Behaviour Research and Therapy, 37(11), 1029-1054. https://doi. org/10.1016/S0005-7967(98)00200-9.

Ruiz, M., Zamorano, E., García-Campayo, J., Pardo, A., Freire, O., \& Rejas, J. (2011). Validity of the GAD-7 scale as an outcome measure of disability in patients with generalized anxiety disorders in primary care. Journal of Affective Disorders, 128(3), 277-286. https://doi. org/10.1016/j.jad.2010.07.010.

Soto, J., Perez, C., Kim, Y., Lee, E., \& Minnick, M. (2011). Is expressive suppression always associated with poorer psychological functioning? A cross-cultural comparison between European Americans and Hong Kong Chinese. Emotion, 11(6), 1450-1455. https://doi.org/ 10.1037/a0023340.

Spitzer, R. L., Kroenke, K., Williams, J. B., \& Löwe, B. (2006). A brief measure for assessing generalized anxiety disorder: The GAD-7. Archives of Internal Medicine, 166(10), 1092-1097. https://doi. org/10.1001/archinte.166.10.1092.

Tamres, L., Janicki, D., \& Helgeson, V. (2002). Sex differences in coping behavior: A meta analytic review and an examination of relative coping. Personality and Social Psychology Review, 6(1), 2-30.

Wei, M., Su, J., Carrera, S., Lin, S. P., \& Yi, F. (2013). Suppression and interpersonal harmony: A cross-cultural comparison between Chinese and European Americans. Journal of Counseling Psychology, 60(4), 625-633.

Yoon, S., Dang, V., Mertz, J., \& Rottenberg, J. (2018). Are attitudes towards emotions associated with depression? A conceptual and meta-analytic review. Journal of Affective Disorders, 232, 329-340.

Publisher's Note Springer Nature remains neutral with regard to jurisdictional claims in published maps and institutional affiliations. 